\title{
Effect of legume varieties and fermentation time of tempe using usar inoculum on the inhibitory activity of angiotensin I-converting enzyme
}

\author{
RETNO INDRATI, MARTA T. HANDAYANI, NOVIA A. RAHAYU, SUCI A. PEBRIANTI \\ Faculty of Agricultural Technology, Universitas Gadjah Mada. Jl. Flora No. 1, Bulaksumur, Sleman 55281, Yogyakarta, Indonesia. \\ Tel./fax.: +62-274-589797, `email: indrati@ugm.ac.id
}

Manuscript received: 9 July 2021. Revision accepted: 9 October 2021.

\begin{abstract}
Indrati R, Handayani MT, Rahayu NA, Pebrianti SA. 2021. Effect of legume varieties and fermentation time of tempe using usar inoculum on the inhibitory activity of angiotensin I-converting enzyme. Biodiversitas 22: 5262-5267. The effect of three varieties of legumes, namely, velvet bean (Mucuna prurient), lima bean (Phasaelus lunatus L.), and pigeon pea (Cajanus cajan), on the activity of angiotensin I-converting enzyme (ACE) inhibitors was studied during tempe fermentation. Fermentation is one way to produce bioactive peptides. Furthermore, the effect of inoculum usar on tempe fermentation was studied. Hydrophobic amino acids are essential in binding firmly to the active site of ACE, and the research showed that pigeon pea had higher levels of hydrophobic amino acids compared with soybeans. The legumes affected the protease activity, peptide content, degree of hydrolysis, and production of ACE inhibitory (ACEI) activity during tempe fermentation. High protein levels and peptide content did not guarantee a high ACE inhibitor level. The mixed culture of usar caused no effect on the production of ACE inhibitors compared with a single culture of Raprima. Legume beans that reached optimal fermentation fast produced high levels of ACE inhibitors. Of the three types of legumes tested in the study, lima beans had the highest ACEI activity during fermentation.
\end{abstract}

Keywords: ACE inhibitor, legumes, tempe, usar

\section{INTRODUCTION}

Legumes are foods rich in protein and nutrients, such as antioxidant compounds, resistant starch, dietary fiber, and others (Zhang et al. 2015; Kan et al. 2017). Therefore, legumes are a healthy and inexpensive source of nutrition. Given their high protein content, legumes have been widely studied, especially regarding their health benefits. In addition, legumes have various varieties with varying levels of protein and amino acid composition. These factors will determine their usefulness as important bioactive compounds, especially bioactive peptides, for body health. Peptides with low molecular weight are often referred to as bioactive peptides because of their excellent physiological functions: (i) prevention of heart disease, cancer, osteoporosis, and menopause symptom of chronic diseases; (ii) lowering of cholesterol levels to protect against heart disease; (iii) lowering of lipid levels in the blood (lowering low-density lipoprotein levels and increasing high-density lipoprotein levels); (iv) inhibition of the angiotensin Iconverting enzyme (ACE) activity to lower blood pressure (Soumya et al. 2021).

The treatment of diabetes, hypertension, and chronic diseases widely uses bioactive peptides through healthy functional foods (Xu et al. 2019). Examples include the bioactive peptides in fermented milk (Beltrán-Barrientos et al. 2016), cereal-based fermented foods from Turkey (Kabak and Dobson 2011), the fermented soy food douche (Zhang et al. 2006), and others. In addition, hypertension is a significant risk factor for coronary heart disease, kidney disease, and stroke (Hajar 2017). Therefore, the potential of an ingredient containing antihypertensive functional compounds must be measured, and one method to achieve such goal is to determine their inhibitory activity on ACE.

The process for producing bioactive peptides can occur through (i) enzymatic protein hydrolysis and (ii) proteolytic degradation by microorganisms (Toldrá et al. 2018). The fermentation of protein-rich food ingredients is one way to derive products with higher nutrition, improved sensory properties, and healthy bioactive peptides due to the protein degradation by microbes involved in fermentation (Udenigwe and Aluko 2012; Martinez-Villaluenga et al. 2017).

Tempe is a traditional Indonesian food made by fermenting beans (jack bean, velvet bean, and others). Soybean tempe is often found in traditional/modern markets. In rural areas, tempe productions still use the traditional tempe inoculum (called usar), which contains a mixed culture of fungi in Hibiscus leaves. However, a commercial type of inoculum (known as Raprima) is used in urban areas and contains a potential fungal strain, Rhizopus oligosporus. Along with the increasing public awareness about body health, the consumption of tempe also increases. The increase in vegetarian/vegan communities has also led to the increased consumption of plant foods, one of which is tempe which serves as a protein source. From Indonesian Central Statistics Agency data (BPS 2020), soybean imports have increased throughout 2009-2019. From the side of tempe craftsmen, soybean raw materials, which are still dependent on imports, have revived the traditional tempe-making business, such as jack bean tempe and others that once existed in the community (Erina 2021). Several tempes made from legumes, which contain bioactive peptide ACE inhibitors, have been investigated using the commercial 
inoculum Raprima. However, the research on ACE inhibitory (ACEI) activity in tempe from legumes inoculated with usar has not been reported.

This research studied the effect of three varieties of legumes and inoculum usar on their ability to produce ACEI compounds. The legumes studied included velvet bean (Mucuna prurient), lima bean (Phasaelus lunatus L.), and pigeon pea (Cajanus cajan). In addition, the results were compared with the tempe made from the same legumes inoculated with Raprima and the reported tempe made from jack bean legume (Canavalia ensiformis).

\section{MATERIALS AND METHODS}

\section{Materials}

Velvet beans (Mucuna prurient), lima beans (Phasaelus lunatus L.), pigeon pea beans (Cajanus cajan), and usar were obtained from a local market in Yogyakarta, Indonesia. Hippuryl-L-histidyl-L-leucine, ACE (EC 3.4.15.1 from rabbit lung), trichloroacetic acid (TCA), and tryptone standard were from Sigma-Aldrich. FolinCiocalteu and $o$-phthaldialdehyde (OPA) were from Merck. All other chemicals used were analytical grade.

\section{Sample preparation and tempe fermentation}

The beans were washed and soaked for $24 \mathrm{~h}$. The soaked beans were boiled for $30 \mathrm{~min}$ followed by manual dehulling and then soaked for the second time for up to 24 $\mathrm{h}$, in accordance with the method of Puspitojati et al. (2019a). Afterward, the beans were cooked for $10 \mathrm{~min}$, drained, and cooled to room temperature $\left( \pm 29^{\circ} \mathrm{C}\right)$. Inoculation was performed using usar (traditional tempe inoculum, one leaf for $1 \mathrm{~kg}$ seed). The inoculated beans were packed in banana leaves and fermented at $\pm 29^{\circ} \mathrm{C}$ for $0-120 \mathrm{~h}$. The analysis was conducted every $12 \mathrm{~h}$. The resulting sample at each fermentation time was lyophilized and stored for further analysis.

\section{Protein, peptide, and protease extraction}

The protein content of beans was analyzed using the Kjeldahl method (AOAC 2005). Protein, peptide, and protease extraction were carried out using the dried powder of tempe based on a modified method by Puspitojati et al. (2019b). The dried sample $(1 \mathrm{~g})$ was blended with $30 \mathrm{~mL}$ distilled water, followed by homogenization for $3 \mathrm{~min}$ using a food chopper, and then incubated in a water bath shaker for $60 \mathrm{~min}\left(60 \mathrm{rpm}, 30^{\circ} \mathrm{C}\right)$. The supernatant containing protein, peptide, and protease was collected for further analysis after centrifugation at $20,000 \mathrm{~g}$ for $15 \mathrm{~min}$ at $\pm 29^{\circ} \mathrm{C}$.

\section{Determination of protease activity}

Protease activity was measured quantitatively by the Sigma-Aldrich method with slight modifications. A total of $5 \mathrm{~mL} 0.65 \%$ casein solution was incubated for $5 \mathrm{~min}$ at $37^{\circ} \mathrm{C}$ in a water bath, added with $1 \mathrm{~mL}$ protease enzyme solution, and incubated at $37^{\circ} \mathrm{C}$ for $10 \mathrm{~min}$. After incubation, $5 \mathrm{~mL}$ TCA reagent was added to stop the reaction, and centrifugation was performed at $6000 \mathrm{rpm}$ for
$10 \mathrm{~min}$. Then, $2 \mathrm{~mL}$ supernatant was obtained and added with $5 \mathrm{~mL}$ sodium carbonate and $1 \mathrm{~mL}$ Folin. The mixture was mixed evenly, and absorbance was measured at 660 nm. Protease activity (one Unit) was expressed as the number of enzymes producing $1 \mu \mathrm{mol}$ tyrosine per min under test conditions (Pebrianti 2019).

\section{Determination of peptide content and degree of hydrolysis (DH)}

The measurement of peptide concentration was determined by using OPA by Church et al. (1983). In addition, Lin et al.'s method (2017) with slight modifications was used to determine the DH. The sample powder was hydrolyzed with $8 \mathrm{M} \mathrm{HCl}(1: 10 \mathrm{w} / \mathrm{v})$ for $24 \mathrm{~h}$ at $110^{\circ} \mathrm{C}$. Then, the sample was neutralized with $8 \mathrm{M}$ $\mathrm{NaOH}$, and distilled water was added to attain the total volume of $10 \mathrm{~mL}$. The mixture was filtered, and the peptide concentration was analyzed using the OPA reagent. The absorbance was monitored at $\lambda=340 \mathrm{~nm}$, and tryptone was used to generate the standard curve. The calculation of DH was performed using the following formula:

$$
\mathrm{DH}(\%)=\frac{\left(\mathrm{NH}_{2}\right)_{\mathrm{tx}}-\left(\mathrm{NH}_{2}\right)_{\mathrm{t} 0}}{\left(\mathrm{NH}_{2}\right)_{\mathrm{total}}-\left(\mathrm{NH}_{2}\right)_{\mathrm{t} 0}}
$$

Where: $\left(\mathrm{NH}_{2}\right)$ is the number of free amino groups, tx $\underline{x}$ at $\mathrm{x} \mathrm{min}, \mathrm{t}_{0}$ is at $0 \mathrm{~min}$ of hydrolysis, and $\left(\mathrm{NH}_{2}\right)_{\text {total }}$ is the total number of amino groups.

\section{Analysis of amino acid composition}

Liquid chromatography with tandem mass spectrometry (LC-MS/MS) was used to analyze the amino composition of the beans. The sample was hydrolyzed in an autoclave for $12 \mathrm{~h}$ at $110^{\circ} \mathrm{C}$ using $6 \mathrm{~N} \mathrm{HCl}$. Then, the samples were neutralized using $6 \mathrm{~N} \mathrm{NaOH}$, filtered using a $0.22 \mu \mathrm{m}$ paper filter, and diluted with $\mathrm{H}_{2} \mathrm{O}$ at a ratio of 1:50 (v/v). Then, $2 \mu \mathrm{L}$ sample was injected into the LC-MS/MS equipment (ACQUITY UPLC BEH C18 Column, $130 \AA$, $1.7 \mu \mathrm{m}, 2.1 \mathrm{~mm} \times 50 \mathrm{~mm})$. The solvents used were as described by Chang et al. (1989) as follows: (i) A: $0.1 \%$ formic acid with $0.1 \%$ penta-decafluorooctanoic acid (PDFOA):water $/ \mathrm{CH}_{3} \mathrm{CN} \quad(0.5: 99.5)$, (ii) $\mathrm{B}: 0.1 \%$ formic acid with $0.1 \%$ PDFOA:water/ $\mathrm{CH}_{3} \mathrm{CN}$ (90:10)

The sample was eluted for $1.5 \mathrm{~min}$ at $50^{\circ} \mathrm{C}$ in solvent $\mathrm{A}$ and $0.5 \mathrm{~min}$ in solvent $\mathrm{B}$ at a $0.6 \mathrm{~mL} / \mathrm{min}$ flow rate. The total hydrophobic amino acids for each sample were then calculated.

\section{ACEI activity}

The ACEI activity of the hydrolysate was measured by the method of Chusman and Cheung (1971). Next, $50 \mu \mathrm{L}$ sample solution and $50 \mu \mathrm{L}$ ACE solution $(25 \mathrm{mU} / \mathrm{mL})$ were mixed and then incubated at $37^{\circ} \mathrm{C}$ for $10 \mathrm{~min}$. Afterward, $50 \mu \mathrm{l}$ substrate was added $(8 \mathrm{mM}$ Hip-His-Leu in $50 \mathrm{mM}$

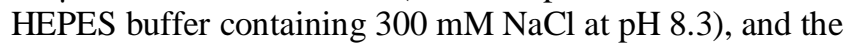
incubation was continued at $37^{\circ} \mathrm{C}$ for $30 \mathrm{~min}$. $\mathrm{HCl}(1 \mathrm{M}$, $200 \mu \mathrm{L}$ ) was added to stop the reaction. Then, the mixture was added with ethyl acetate $(1.5 \mathrm{~mL})$, stirred for $2 \mathrm{~min}$, and centrifuged (4000 g) for $15 \mathrm{~min}$. The supernatant (1 $\mathrm{mL}$ ) was transferred to another glass tube and evaporated 
in boiling water for $30 \mathrm{~min}$. The resulting dry sample was dissolved in $3 \mathrm{~mL}$ distilled water, and absorbance was measured at $\lambda=228 \mathrm{~nm}$. The ACEI activity was calculated as the percentage inhibition of ACE activity using the formula:

$$
\operatorname{ACEI} \text { activity }(\%)=\frac{(\mathrm{Ac}-\mathrm{As})}{(\mathrm{Ac}-\mathrm{Ab})} \times 100 \%
$$

Where: Ac is the absorbance of the ACE + substrate (control), As is the absorbance of the substrate + ACE + sample, and $\mathrm{Ab}$ is the absorbance of the substrate + sample (blank). $\mathrm{IC}_{50}$ is the sample concentration that can inhibit ACE activity by $50 \%$.

\section{Statistical analysis}

Data were processed using one-way analysis of variance with a 95\% significance level. A follow-up test was conducted using Duncan's multiple range test when significant differences were detected. This study was carried out with three replications, and the results were averaged.

\section{RESULTS AND DISCUSSION}

\section{Protein and hydrophobic amino acid content of various legume seeds}

Protein content will determine the number of peptides that will be produced after hydrolysis. A higher protein content is considered more accessible to use and form ACEI peptides than other sources with limited protein content (Udenigwe and Aluko 2012). Table 1 shows the protein content of the various legumes. The three legumes studied have high protein contents of about $20.06 \%$ (lima beans) to $26.75 \%$ (velvet beans). The protein content of these legumes is lower than that of jack beans and soybeans. However, these legumes are traditionally used to make tempe. To date, legume tempe can still be found, for example, velvet bean tempe, which is a typical food in the areas of Yogyakarta (Kulon Progo), Central Java (Magelang and Wonogiri), and East Java (Pacitan), which are all on the island of Java, Indonesia.

Table 1 also shows the percentage of total hydrophobic amino acids per protein weight. Hydrophobic amino acids are essential for ACE inhibition. They bind strongly to the active site, primarily hydrophobic amino acids located at the $\mathrm{C}$ terminal of ACEI peptides, such as Trp, Tyr, Phe, and Pro (Wu et al. 2016). Hence, the potential formation of bioactive peptides must be determined. In addition to hydrophobic amino acids, negatively charged amino acids can form bioactive peptides that inhibit ACE activity. They can engage in an electrostatic interaction with $\mathrm{Zn}^{2+}$ as a coenzyme of ACE (Tuz and Campos 2017; Wu et al. 2016). The three legumes studied contain sufficiently high amounts of hydrophobic amino acids. Thus, these legumes can also produce ACE inhibitors bioactive peptides, such as those found in soybeans or jack beans. Especially, velvet bean has a high hydrophobic amino acid content similar to jack bean.

Meanwhile, lima beans have the lowest protein content and low levels of hydrophobic amino acids. The seed varieties, ecological diversity, different harvest, postharvest handling, and storage conditions influence the differences in the quantity and quality of protein in beans in different geographic locations (Sridhar and Seena 2006; Kachare et al. 2019). Seidu et al. (2015) reported that the hydrophobic amino acid content of lima beans ranged from $40.61 \%$ to $42.14 \%$ by protein weight, with a protein content of $14.53 \%-15.93 \%$ dry weight. These reported data differed from those in this study.

\section{Effect of legume varieties on tempe characteristics during fermentation}

Given their high protein content, three legumes were used to prepare tempe using usar inoculum. Every $12 \mathrm{~h}$, several parameters were observed (Figure 1). Figure 1A shows the changes in the protease activity pattern during the fermentation of three types of legumes. The protease activity, which increased during fermentation, showed the same pattern. Pigeon pea beans had the highest protease activity, whereas lima beans exhibited the lowest. In general, in regulating metabolism, the presence of substrate encourages microbes (in this case, fungi from usar inoculum) to produce their degrading enzymes. Given this condition, high protein levels result in high protease levels. As the mycelium of fungi appeared thick, and the texture of pigeon pea tempe became compact, the proteolytic activity also continually increased significantly $(\mathrm{P}<0.05)$ with fermentation time. The same pattern of proteolytic activity was also reported by Ruiz-Teran and Owens (1996) in soybean tempe, Starzyńska-Janiszewska et al. (2015) in grass pea tempe fermented by Rhizopus microsporus var. Chinensis and Aspergillus oryzae, and Puspitojati et al. (2019b) in jack bean tempe fermented by commercial starter Raprima containing Rhizopus oligosporus. Thus, this result indicates that no difference occurred in the proteolytic activity patterns in either a single culture of Raprima or mixed culture of usar. The proteolysis during tempe fermentation is essential and will significantly affect the formation and generation of ACE inhibitor peptides (Puspitojati et al. 2019b).

Table 1. Protein content and hydrophobic amino acids of several legume varieties

\begin{tabular}{|c|c|c|c|c|c|}
\hline \multirow{2}{*}{ Subtance } & \multicolumn{5}{|c|}{ Legumes } \\
\hline & Velvet bean & Lima bean & Pigeon pea & Jack bean $^{1}$ & Soybean \\
\hline Protein $(\mathrm{db}, \% \mathrm{w} / \mathrm{w})$ & $26.75 \pm 1.29$ & $20.06 \pm 0.20$ & $22.78 \pm 0.51$ & $31.33 \pm 1.52$ & $35.35-39.80^{2}$ \\
\hline $\begin{array}{l}\text { Hydrophobic amino acid (db, \% } \\
\text { w/w protein) }\end{array}$ & $27.44 \pm 0.05$ & $6.96 \pm 0.39$ & $24.55 \pm 0.08$ & $28.78 \pm 0.07$ & $37.70^{3}$ \\
\hline
\end{tabular}

Note: db: dry basis; ${ }^{1}$ Puspitojati et al. (2019a); ${ }^{2}$ Ciabotti et al. (2016); ${ }^{3}$ Sridhar and Seena (2006) 
The protease activity data in Figure $1 \mathrm{~A}$ are in line with those on the DH shown in Figure 1B, that is, pigeon peas had the highest DH. However, at $12 \mathrm{~h}$, the value was still lower than that of velvet beans. When the pigeon peas were fermented for $120 \mathrm{~h}$, the tempe texture became very soft and dark in color due to over-fermentation. Therefore, pigeon peas were fermented for $96 \mathrm{~h}$ only. StarzyńskaJaniszewska et al. (2015) showed that the DH increased along with fermentation time in their experiment on fermenting grass pea tempe using Rhizopus spp. and Aspergillus. This report confirms that protease activity affects the hydrolysis rate; the higher the protease activity, the more peptides are produced, resulting in a higher DH. Another factor is the variety of the legume itself. Figure 1C shows that pigeon peas had the highest peptide content and protease activity. However, the case was slightly different for lima beans. At 96-120 h of fermentation, the peptide content of lima beans was higher than that of velvet beans, although the protease activity was low. During this time, the DH increased sharply (Figure 1B).

Figure 1D shows that the patterns of ACEI activity in the three legumes were similar and followed the growth pattern of fungal mycelia (data not shown). The ACEI activity was optimum at $48-72 \mathrm{~h}$ of fermentation. The growth pattern of this fungus was similar to that of other fermented tempe made from soybeans (optimal at $32 \mathrm{~h}$; Nout and Kiers 2005) or koro beans (optimal at $72 \mathrm{~h}$; Puspitojati et al. 2019a). Thus, the pattern of ACEI activity did not follow that of the peptide levels, which increased with fermentation time (Figure 1C). ACE inhibitors are bioactive peptides with specific protein fragments and low molecular weight (2-20 amino acids). The constituent amino acids are hydrophobic (Himaya et al. 2012). The highest inhibitory activity was observed in the lima bean tempe fermented for $48 \mathrm{~h}(83.9 \%)$. These data indicate that a high peptide content does not always guarantee the most increased ACEI activity, as suggested by Puspitojati et al. (2019b). Likewise, high protein and hydrophobic amino acid content do not necessarily result in high ACEI activity, such as that in velvet pea (Table 1 and Figure 1D). Table 1 shows that lima beans had the lowest protein and hydrophobic amino acids among the three legumes. This result may be related to peptides with negatively charged amino acids (Asp and Glu) found in lima bean $(4.48 \% \pm$ $0.51 \%$ dry protein). Several researchers (Udenigwe and Mohan 2014; Daskaya-Dikmen et al. 2017; Lin et al. 2017) reported that negatively charged amino acids can increase the ACEI activity due to the binding of $\mathrm{Zn}$ atoms by these negatively charged amino acids. Zn atoms are essential for ACE activity.
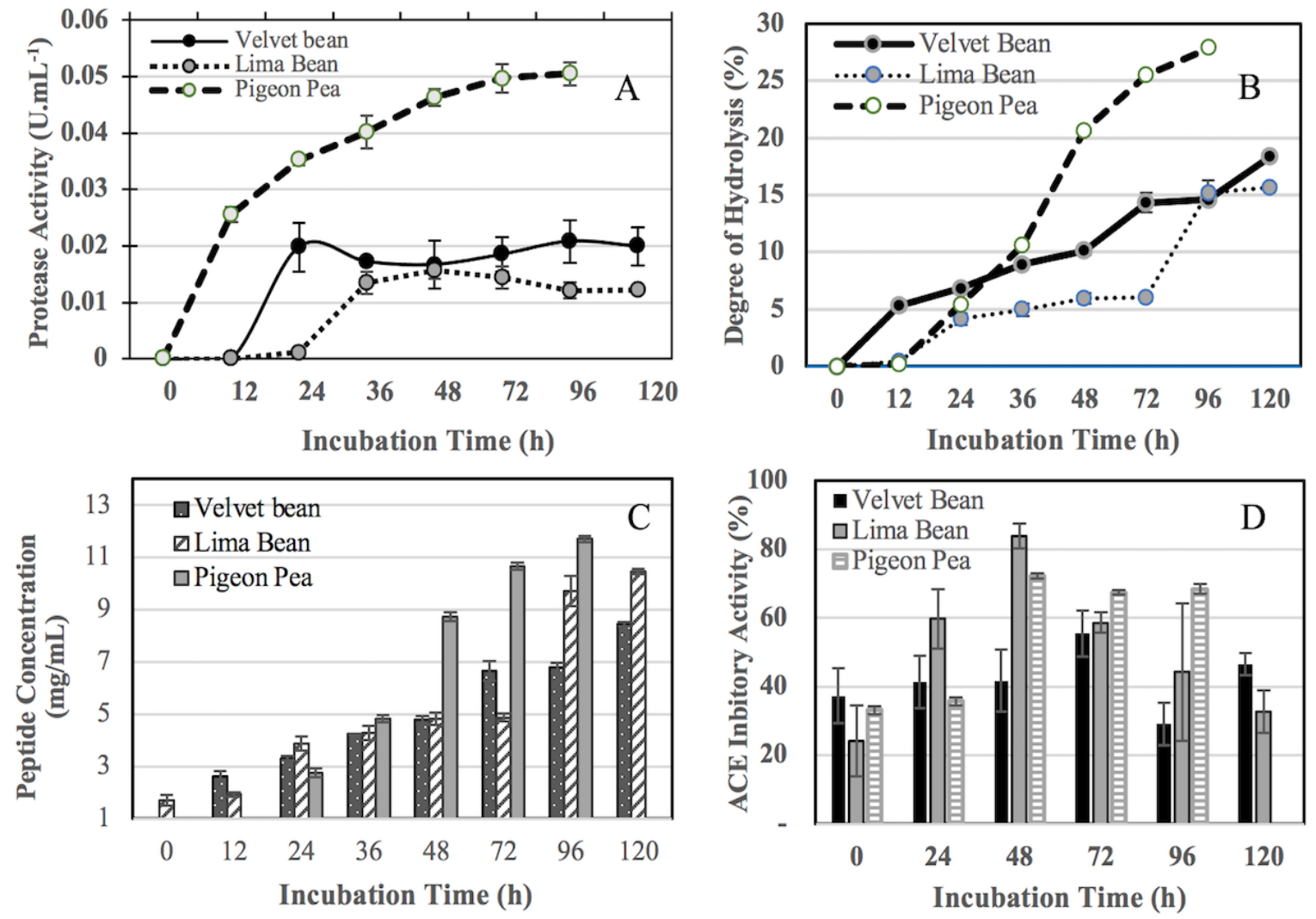

Figure 1. Effect of legume varieties on tempe characteristics during fermentation using usar as an inoculum. A. Changes in protease activity, B. Changes in a DH, C. Changes in peptide content, D. Changes in ACEI activity 
Table 2. Optimum fermentation time, production of ACEI and $\mathrm{IC}_{50}$ of tempe made from several legume varieties inoculated with traditional inoculum (usar) compared with the reported commercial inoculum

\begin{tabular}{|c|c|c|c|c|c|c|}
\hline \multirow{3}{*}{ Legumes } & \multicolumn{6}{|c|}{ Inoculum } \\
\hline & \multicolumn{3}{|c|}{ Usar $^{1}$} & \multicolumn{3}{|c|}{ Raprima $^{2}$} \\
\hline & ACEI (\%) & Time $(h)^{3}$ & $\mathrm{IC}_{50}(\mathrm{mg} / \mathrm{mL})$ & ACEI (\%) & Time $(h)^{3}$ & $\mathrm{IC}_{50}(\mathrm{mg} / \mathrm{mL})$ \\
\hline Velvet Bean & $55.6 \pm 6.7$ & 72 & 1.07 & $59.2 \pm 1.9^{4}$ & 72 & 0.86 \\
\hline Lima Bean & $83.9 \pm 3.6$ & 48 & 0.77 & $85.0^{5}$ & 48 & 0.76 \\
\hline Pigeon Pea & $72.3 \pm 0.8$ & 48 & 0.74 & $76.1^{6}$ & 48 & 0.65 \\
\hline Jack Bean ${ }^{\mathbf{7 , 8}}$ & 53.9 & 72 & NA & 60.04 & 72 & 1.03 \\
\hline
\end{tabular}

Note: NA: data not available. ${ }^{1}$ usar, traditional inoculum (this study); ${ }^{2}$ Raprima, commercial inoculum; ${ }^{3}$ time (h), optimum fermentation time (h); ${ }^{4}$ Rahayu 2019 (for Raprima data); ${ }^{5}$ Handayani 2019 (for Raprima data); ${ }^{6}$ Pebrianti et al. 2019 (for Raprima data); ${ }^{7}$ Puspitojati et al.2019a (for $u$ sar data); ${ }^{8}$ Puspitojati et al. $2019 \mathrm{~b}$ (for Raprima data)

\section{Effect of type of inoculum on ACEI activity and IC50}

Table 2 shows that the difference in inoculum did not affect the production of ACEI activity. The more decisive factor was the variety of legumes used. Velvet bean tempe had the lowest ACE inhibitor, resulting in the highest $\mathrm{IC}_{50}$. Its protein and hydrophobic amino acid content were the highest among the three legumes studied. This ACEI activity of velvet beans is similar to that reported for jack bean tempe (Puspitojati 2019a; 2019b). The optimal fermentation time is affected not by the type of inoculum but by the variety of legumes, especially the hardness of beans. Velvet bean tempe required a longer fermentation time $(72 \mathrm{~h})$ to reach its optimum value than the other two legumes. The results are similar to the fermentation time of jack bean tempe (Puspitojati 2019a; 2019b). Compared with soybean tempe, which was optimal at $32 \mathrm{~h}$ incubation (Nout and Kiers 2005), the tempe of the studied legumes needed a longer fermentation period. The seeds were more difficult to degrade and more prominent in size than soybeans. Table 2 shows that when the beans reached optimum fermentation fast, high levels of ACE inhibitor production and low $\mathrm{IC}_{50}$ were observed (lima beans and pigeon pea).

In conclusion, this study concluded that the types of legumes affect the protease activity, peptide content, DH, and production of ACEI activity during the tempe fermentation process. Mixed cultures (usar) showed no effect on the production of ACE inhibitors in the same legume variety compared with a single culture. The fast optimum bean fermentation resulted in a high ACE inhibitor production. High protein levels and peptide content do not guarantee a high level of ACE inhibitor. Of the three types of legumes tested in the study, lima beans produced the highest ACEI activity during fermentation.

\section{ACKNOWLEDGEMENTS}

The authors are thankful for the financial support under project No. 1778/UN1/DITLIT/DIT-LIT/LT/2018 by the grant from the Ministry of Education and Culture of the Republic of Indonesia. The authors declare no conflict of interest.

\section{REFERENCES}

AOAC. 2005. Official methods of analysis of AOAC International, 18th Ed. Gaithersburg, Maryland.

Beltrán-Barrientos LM, Hernández-Mendoza A, Torres-Llanez MJ, González-Córdova AF, Vallejo-Córdoba B. 2016. Invited review: Fermented milk as antihypertensive functional food. J Dairy Sci 99 (6): 4099-4110. DOI: $10.3168 /$ jds.2015-10054.

BPS. 2020. Soybean Imports by Main Country of Origin, 2010-2019. Last update 17 April 2020. Indonesian Central Statistics Agency https://www.bps.go.id/statictable/2019/02/14/2015/impor-kedelaimenurut-negara-asal-utama-2010-2019.html. [Indonesian] [28 May 2021]

Chang KC, Skauge LH, Satterlee LD. 1989. Analysis of amino acids in soy isolates and navy beans using precolumn derivatization with phenylisothiocyanate and reversed-phase high performance liquid chromatography. J Food Sci 54 (3): 756-759.

Church FC, Swaisgood HE, Porter DH, Catignani GL. 1983. Spectrophotometric assay using ophthaldialdehyde for determination of proteolysis in milk and isolated milk proteins. J. Dairy Sci 66 (6): 1219-1227.

Chusman DW, Cheung HW. 1971. Spectrophotometric assay and properties of the angiotensin-converting enzyme of the rabbit lung. Biochem Pharmacol 20 (7): 1637-1648. DOI: 10.1016/00062952(71)90292-9.

Ciabotti S, Silva ACBB, Juhaz ACP, Mengonca CD, Tavano O, Mandarino JMG, Goncalves CAA. 2016. Chemical composition, protein profile, and isoflavones content in soybean genotypes with different seed coat colors. Intl Food Res J 23 (2): 621-629.

Daskaya-Dikmen C, Yucetepe A, Karbancioglu-Guler F, Daskaya H, Ozcelik B. 2017. Angiotensin-I-converting enzyme (ACE)-inhibitory peptides from plants. Nutrients 9 (4): 316. DOI: 10.3390/nu9040316.

Erina R. 2021. Not dependent on soybeans, this entrepreneur is successful with the tempe koro and green beans business. Political News Agency of the Republic of Indonesia https://ekbis.rmol.id/read/2021/01/13/470364/tidak-tergantungdengan-kedelai-pengusaha-ini-sukses-dengan-bisnis-tempe-koro-dankacang-hijau. [Indonesian] [ 21 May 2021]

Hajar R. 2017. Risk factors for coronary artery disease: Historical perspectives. Heart Views 18 (3): 109-114. DOI: 10.4103/HEARTVIEWS.HEARTVIEWS_106_17.

Handayani MT. 2019. The Effect of Fermentation Time on Production of Bioactive Peptide ACE inhibitory from Tempe Koro Kratok (Phaseolus lunatus) Inoculated with Rhizopus oligosporus. [Thesis]. Universitas Gadjah Mada, Yogyakarta. [Indonesian]

Himaya SWA, Ngo DH, Ryu B, Kim SK. 2012. An active peptide purified from gastrointestinal enzyme hydrolysate of Pacific cod skin gelatin attenuates angiotensin I converting enzyme activity and cellular oxidative stress. Food Chem 132 (4): 1872-1882. DOI: 10.1016/j.foodchem.2011.12.020.

Kabak B, Dobson ADW. 2011. An Introduction to the Traditional Fermented Foods and Beverages of Turkey. Critical Rev Food Sci Nutr 51 (3): 248-260. DOI: 10.1080/10408390903569640. 
Kachare DP, Satbhai RD, Rathod DB, Naik RM. 2019. Evaluation of pigeon pea (Cajanus cajan L.) genotypes for nutritional quality. Legume Res 42 (4): 485-489. DOI: 10.18805/LR-3899.

Kan L, Nie S, Hu J, Wang S, Cui SW, Li Y, Xu S, Wu Y, Wang J, Bai Z, Xie M. 2017. Nutrients, phytochemicals and antioxidant activities of 26 kidney bean cultivars. Food Chem Toxic 108: 467-477. DOI: 10.1016/j.fct.2016.09.007.

Lin HC, Alashi AM, Aluko RE, Pan BS, Chang YW. 2017. Antihypertensive properties of tilapia (Oreochromis spp.) frame and skin enzymatic protein hydrolysate. Food Nut Res 61: 1391666. DOI 10.1080/16546628.2017.1391666.

Martinez-Villaluenga C, Peñas E, Frias J. 2017. Chapter 2-Bioactive Peptides in fermented foods: Production and evidence for health effects fermented foods in health and disease prevention. In: Frías J, Martínez-Villaluenga C, Peñas E. (eds.). Fermented Foods in Health and Disease Prevention (1st Edition). Academic Press, Cambridge.

Nout MJR, Kiers JL. 2005. Tempe fermentation, innovation, and functionality: Update into the third millennium. J Appl Microbiol 98 (4): 789-805. DOI: 10.1111/j.1365-2672.2004.02471.x.

Pebrianti SA. 2019. Angiotensin Converting Enzyme (ACE) Inhibition Activity from ACE Inhibitor Peptide Produced During Fermentation of Tempe Gude (Cajanus cajan). [Thesis]. Universitas Gadjah Mada, Yogyakarta. [Indonesian]

Pebrianti SA, Cahyanto MN, Indrati R. 2019. Angiotensin I-converting enzyme (ACE) inhibitory activity of ACE inhibitory peptides produced during the fermentation of pigeon pea (Cajanus cajan) tempe. Indonesian Food Nutr Progr 16 (2): 47-52. DOI: 10.22146/ifnp.46921

Puspitojati E, Cahyanto MN, Marsono Y, Indrati R. 2019a. Formation of ACE-inhibitory peptides during fermentation of jack bean tempe inoculated by usar Hibiscus tiliaceus leaves starter. IOP Conf Ser Earth Environ Sci 292: 012022. DOI: 10.1088/17551315/292/1/012022.

Puspitojati E, Cahyanto MN, Marsono Y, Indrati R. 2019b. Production of angiotensin-i-converting enzyme (ACE) inhibitory peptides during the fermentation of jack bean (Canavalia ensiformis) tempe. Pak J Nutr18 (5): 464-470. DOI: 10.3923/pjn.2019.464-470.

Rahayu NA. 2019. Effect of Fermentation Time on ACE Inhibitor Activity of Extract and Dialysis Fraction of Peptide Velvet Bean Tempe (Mucuna pruriens). [Thesis]. Universitas Gadjah Mada, Yogyakarta. [Indonesian]

Ruiz-Teran F, Owens JD. 1996. Chemical and enzymic changes during the fermentation of bacteria-free soya bean tempe. J Sci Food Agr 71: 523-530. DOI: 10.1002/(SICI)1097-0010(199608)71:4<523::AIDJSFA613>3.0.CO;2-R.
Seidu KT, Osundahunsi OF, Olaleye MT, Oluwalana, IB. 2015. Amino acid composition, mineral contents and protein solubility of some lima bean (Phaseolus lunatus 1. Walp) seeds coat. Food Res Int1 73: 130-134. DOI: 10.1016/j.foodres.2015.03.034.

Soumya NP, Mini S, Sivan S, Mondal S. 2021. Bioactive compounds in functional foods and their role as therapeutics. Bioactive Compounds Health Dis 4 (3): 24-39. DOI: 10.31989/bchd.v4i3.786.

Sridhar KR, Seena S. 2006. Nutritional and antinutritional significance of four unconventional legumes of the genus Canavalia: A comparative $\begin{array}{llll}\text { study. Food Chem } 99 & \text { (2): 267-288. DOI: }\end{array}$ 10.1016/j.foodchem.2005.07.049.

Starzyńska-Janiszewska A, Stodolak B, Wikiera A. 2015. Proteolysis in tempeh-type products obtained with Rhizopus and Aspergillus strains from grass pea (Lathyrus sativus) seeds. Acta Sci Pol Technol Aliment 14 (2): 125-132. DOI: 10.17306/J.AFS.2015.2.14

Toldrá F, Reig M, Aristoy MC, Mora L. 2018. Generation of bioactive peptides during food processing. Food Chem 267: 395-404. DOI: 10.1016/j.foodchem.2017.06.119

Tuz MAO, Campos MRS. 2017. Purification of Mucuna pruriens L. peptide fractions and evaluation of their ACE inhibitory effect. Biocatalys Agric Biotechnol 10: 390-295. DOI: 10.1016/j.bcab.2017.05.001.

Udenigwe CC, Aluko RE. 2012. Food protein-derived bioactive peptides: Production, processing, and potential health benefits. J Food Sci 71 (1): 11-24. DOI: 10.1111/j.1750-3841.2011.02455.x.

Udenigwe CC, Mohan A. 2014. Mechanisms of food protein-derived antihypertensive peptides other than ACE inhibition. J Funct Foods 8: 45-52. DOI: 10.1016/j.jff.2014.03.002.

Wu Q, Du J, Jia J, Kuang C. 2016. Production of ACE inhibitory peptides from sweet sorghum grain protein using alcalase: Hydrolysis kinetic, purification and molecular docking study. Food Chem 199: 140-149. DOI: 10.1016/j.foodchem.2015.12.012.

Xu Q, Hong H, Wu J, Yan X. 2019. Bioavailability of bioactive peptides derived from food proteins across the intestinal epithelial membrane: A review. Trends Food Sci Technol 86 (2): 399-411. DOI: 10.1016/j.tifs.2019.

Zhang JH, Tatsumi E, Ding CH, Li LT. 2006. Angiotensin I converting enzyme inhibitory peptides in douchi, a Chinese traditional fermented soybean product. Food Chem 98 (3): 551-557. DOI: 10.1016/j.foodchem.2005.06.024.

Zhang B, Deng Z, Ramdath DD, Tang Y, Chen PX, Liu R, Liu Q, Tsao R. 2015. Phenolic profiles of 20 Canadian lentil cultivars and their contribution to antioxidant activity and inhibitory effects on $\alpha$ glucosidase and pancreatic lipase. Food Chem 172: 862-872. DOI: 10.1016/j.foodchem.2014.09.144. 